\title{
IN MEMORIAM: Graham W. Irwin
}

from the Columbia University Record, October 25, 1991

Graham W. Irwin, an authority on West African precolonial history, a professor and administrator at $\mathrm{Co}-$ lumbia University for 28 years, and one-time Executive Secretary of the ASA, died October 12 of cancer at his Manhattan home. He was 71 years old.

Until his illness last spring, he had taught courses on West African history, economics, diplomacy, and culture and in the undergraduate core curriculum in Columbia College. He joined the Columbia faculty in 1963 as associate professor, was promoted to professor in 1965, and named professor emeritus in 1988, continuing to teach part-time as a special research scholar.

His interest in African history dated from his appointment in 1958 to the History Department at the newly formed University of Ghana in Accra. According to his colleague, Columbia history professor Marcia Wright, he had been hired to teach European colonialism and, surrounded by historians of Africa, he developed his interest in the Ashanti people and their diplomatic history. His research focused on the precolonial history of West Africa in the 18th and 19th centuries, particularly the Gold Coast, now Ghana.

He also studied the Black African Diaspora and was the author of Africans Abroad: A Documentary History of the Black Diaspora in Asia, Latin Ameri$\mathrm{ca}$, and the Caribbean During the Age of Slavery (Columbia University Press, 1977) and Nineteenth Century Borneo: A Study in Diplomatic Rivalry (The Hague: Martinus Nijhoff, 1955). He was a pioneer in the sixties in the teaching of African history and the Diaspora and in 1973 wrote The African Experience Outside Africa, which was published by Columbia College and used in the core curriculum.

With Columbia historian Richard B. Morris, a scholar of American colonial and constitutional history, he edited the Harper Encyclopedia of the Modern World (Harper \& Row, 1971).

He is survived by his wife of 35 years, Jane T. N. Irwin, and a stepson, Julian K. Wheatley of Ithaca, NY.

Friends wishing to make donations in memory of Graham Irwin may send them to the Africana Library Fund, 314 B Butler Library, Columbia University, New York, NY 10027.

\section{PROVISIONAL MINUTES}

BOARD OF DIRECTORS MEETING

Thursday, November 21, 6:15-9:00 pm and

Friday, November 22, 9:00 am-12:15 pm.

Adam's Mark Hotel, St. Louis.

Present: Directors Martin Klein (Chair), Joel Barkan, Christraud Geary, Sandra Greene, Beverly Grier, Goran Hyden, Edmond Keller, Catharine Newbury, Ann Seidman. Edna Bay (Exec. Dir.), Joseph Miller (Treasurer). Visitor: David Robinson.

\section{Approval of May 18-19 Minutes}

Keller moved and Grier seconded a motion that the minutes be approved as published in ASA News (Jul/Sep 1991). The motion carried.

2. Report of the Executive Director

Bay presented the following written report:

\section{Membership}

The Association continues to show signs of growth and vigor. Membership as of this month is at 2288 individuals and 522 institutions. The 1991 individual membership figure is 17 percent higher than the comparable figure last year. We have 52 ercent more individual members today than we had three years ago.
We have worked out an arrangement with the Canadian Association of African Studies to offer each others' journals to members at reduced subscription rates. That offer will be made on an experimental basis with this year's renewals. If it proves successful, we hope to continue it and possibly develop other ways that our organizations can cooperate.

\section{Finances}

Our accountant reports that we are in reasonably good financial health though our surplus for the 1990-91 fiscal year was considerably less than that in the previous year. Costs have risen most rapidly in the area of staff salary, board expenses, and postage, the latter being a problem beyond our control.

The ASA combined endowed funds showed a balance of $\$ 56,535$ at the end of fiscal 1990-91. That sum has now been enhanced by additional contributions and by the receipt of the first payment from the NEH Challenge Grant, bringing our total of endowed funds to more than $\$ 100,000$.

\section{Publications}

Mark DeLancey assumed his duties as editor of ASR in August. The transition was effected smoothly and the December 1991 issue should be mailed from the printer to the membership during that month.

Harvey Glickman, editor of Issue, has been granted $\$ 25,000$ by the MacArthur Foundation to fund a special issue on conflict resolution.

Four new books have been published or are about to be 